\title{
Laddered Multilevel DC/AC Inverters used in Solar Panel Energy Systems
}

\author{
Fang Lin Luo, Senior Member IEEE \\ Anhui University, HeFei, China 230601 \\ Tel: (86) 0551386 1413, Fax: (86) 0551510 7999, e-mail: luofanglin@ahu.edu.cn
}

\begin{abstract}
Multilevel DC/AC Inverters have various structures. They have many advantages. Unfortunately, most existing inverters content too many components (independent/floating batteries/sources, diodes, Capacitors and switches). The author introduces the "Laddered Multilevel DC/AC Inverters" in this paper that is new approach of the development in this area. Their simple structure and clear operation are obviously different from the existing inverters. Its application in Solar Panel Energy Systems is successful. The simulation and experimental results strongly support our design. We believe that these inverters will draw much attention over the world, and be applied in other renewable energy systems.
\end{abstract}

Keywords-component; Laddered Multilevel DC/AC Inverters, Toggle switch, one-pole two-throw switch, independent/floating batteries, Linear Ladder, Binary Ladder, Luo-Progression (Series) Ladder, Trinary (Ternary) Ladder. Solar Panel Energy Systems, Renewable Energy Systems.

\section{INTRODUCTION}

Multilevel DC/AC Inverters have various structures such as diode-clamped inverter (also called the neutral-point clamped (NPC) inverter), flying capacitor inverters, HBridged inverter and so on [1].

With comparison to PWM DC/AC Inverters, multilevel $\mathrm{DC} / \mathrm{AC}$ Inverters have the advantages (1) the switching flying voltage is low (from one level to next level); (2) the $d i / d t$ and $d v / d t$ is low; (3) The switching frequency is low; (4) THD is better. Unfortunately, most existing inverters content too many components (independent/floating batteries/sources, diodes, Capacitors and switches). For example, a NPC inverter has $\mathrm{n}=(2 \mathrm{~b}+1)$ levels and needs the components are [1 - 3]:

- $4 \mathrm{~b}$ switches,

- 2 b capacitors.

- $\quad(4 b-2)$ diodes

Another, a linear H-Bridged inverter has $\mathrm{n}=(2 \mathrm{~b}+1)$ levels and needs the components are [4 -8]:

- b floating batteries,

- $4 \mathrm{~b}$ switches,

- $4 \mathrm{~b}$ diodes,

where $\mathrm{n}$ is the level number that is always an odd number, $\mathrm{b}$ is the stage number (from the neutral point to the top point) or bridge number.

We introduce few new circuits of multilevel DC/AC Inverters in this paper that are different from the existing multilevel DC/AC Inverters. We call them Laddered
Multilevel DC/AC Inverters. Their structure is simple, and its operation is clear that is new approach of the development in the $\mathrm{DC} / \mathrm{AC}$ inverter area.

\section{PROGRESSIONS (SERIES)}

In Mathematics, a progression is a series of numbers or quantities in which there is always the same relation between each quantity and the one succeeding it. We introduce several progressions in this section. We assume all progressions have the value of their first item V1 is 1 , the value of the general item $\mathrm{i}$ is $\mathrm{Vi}$.

\section{A. Arithmetical Progressions}

Arithmetical progressions are general series. We usually see them as:

- Unit progression;

- Natural number progression;

- Odd number progression.

All arithmetical progressions have the same deference value between the adjacent two items. We define the value of the first item is $\mathrm{V}_{1}$, the value of the general item is $\mathrm{V}_{\mathrm{i}}$, and the deference is $\mathbf{d}$. therefore, the value of the general item $\mathrm{V}_{\mathrm{i}}$ is,

$$
V_{i}=V_{1}+(i-1) d
$$

The sum of the items from the first item to $i^{\text {th }}$ item is $S_{i}$,

$$
S_{i}=i V_{1}+\frac{i(i-1)}{2} d
$$

(1) The Unit progression is listed in Table 1. We assume the last item is $b$, and the value is $V_{b}$. The general item is item $\mathrm{i}$, and the value is $\mathrm{V}_{\mathrm{i}}$. Since the $\mathrm{d}$ is 0 , the sum of the items from 1 to the $i^{\text {th }}$ item is $i$.

Table 1. Unit progression

\begin{tabular}{|c|c|c|c|c|c|c|c|c|}
\hline $\begin{array}{c}\text { Item } \\
\text { No. }\end{array}$ & 1 & 2 & 3 & 4 & $\ldots$ & $\mathrm{i}$ & $\ldots$ & $\mathrm{b}$ \\
\hline Value & 1 & 1 & 1 & 1 & $\ldots$ & 1 & $\ldots$ & 1 \\
\hline $\mathrm{S}_{\mathrm{i}}$ & 1 & 2 & 3 & 4 & $\ldots$ & $\mathrm{i}$ & $\ldots$ & $\mathrm{b}$ \\
\hline
\end{tabular}

(2) The Natural number progression is listed in Table 2. Since the deference $d$ is 1 , the sum of the items from 1 
to the $\mathrm{it}^{\text {th }}$ item is $S_{i}=i+\frac{i(i-1)}{2}$.

Table 2. Natural Number Progression

\begin{tabular}{|c|c|c|c|c|c|c|c|}
\hline $\begin{array}{c}\text { Ite } \\
\mathrm{m} \\
\text { No. }\end{array}$ & 1 & 2 & 3 & 4 & $\mathrm{i}$ & $\cdots$ & $\mathrm{b}$ \\
\hline $\begin{array}{c}\text { Valu } \\
\mathrm{e}\end{array}$ & 1 & 2 & 3 & 4 & $\mathrm{i}$ & $\cdots$ & $\mathrm{b}$ \\
\hline $\mathrm{S}_{\mathrm{i}}$ & 1 & 3 & 6 & 10 & $i+\frac{i(i-1)}{2}$ & $\cdots$ & $b+\frac{b(b-1)}{2}$ \\
\hline
\end{tabular}

(3) The odd-number progression is listed in Table 3. Since the deference $d$ is 2 , the sum of the items from 1 to the $\mathrm{i}^{\text {th }}$ item is $S_{i}=i^{2}$.

Table 3. The odd-number progression

\begin{tabular}{|c|c|c|c|c|c|c|c|}
\hline $\begin{array}{c}\text { Item } \\
\text { No. }\end{array}$ & 1 & 2 & 3 & 4 & $\mathrm{i}$ & $\cdots$ & $\mathrm{b}$ \\
\hline Value & 1 & 3 & 5 & 7 & $2 \mathrm{i}-1$ & $\ldots$ & $2 \mathrm{~b}-1$ \\
\hline $\mathrm{S}_{\mathrm{i}}$ & 1 & 4 & 9 & 16 & $\mathrm{i}^{2}$ & $\cdots$ & $b^{2}$ \\
\hline
\end{tabular}

\section{B: Geometric Progressions}

Geometric progressions are general series. We usually see them as:

- Binary progression;

- Trinary progression (sometimes called Ternary progression).

All geometric progressions have the same proportion between the adjacent two items. We define the proportion is p. therefore, the value of the general item $V_{i}$ is,

$$
V_{i}=V_{1} p^{i-1}
$$

The sum of the items from the first item to $\mathrm{i}^{\text {th }}$ item is $\mathrm{S}_{\mathrm{i}}$,

$$
S_{i}=\frac{p^{i}-1}{p-1} V_{1}
$$

(1) The Binary progression is listed in Table 4 . Since the proportion $\mathrm{p}$ is 2 , the sum of the items from 1 to the $\mathrm{i}^{\text {th }}$ item is $S_{i}=2^{i}-1$.
Table 4. Binary progression

\begin{tabular}{|c|c|c|c|c|c|c|c|c|}
\hline $\begin{array}{c}\text { Item } \\
\text { No. }\end{array}$ & 1 & 2 & 3 & 4 & $\cdots$ & $\mathrm{i}$ & $\cdots$ & $\mathrm{b}$ \\
\hline Value & 1 & 2 & 4 & 8 & $\ldots$ & $2^{\mathrm{i}-1}$ & $\cdots$ & $2^{\mathrm{b}-1}$ \\
\hline $\mathrm{S}_{\mathrm{i}}$ & 1 & 3 & 7 & 15 & $\ldots$ & $2^{\mathrm{i}}-1$ & $\cdots$ & $2^{\mathrm{b}}-1$ \\
\hline
\end{tabular}

(2) The Trinary number progression is listed in Table 5 . Since the proportion $\mathrm{p}$ is 3 , the sum of the items from 1 to the $\mathrm{i}^{\text {th }}$ item is $S_{i}=\frac{3^{i}-1}{2}$.

Table 5. Trinary Progression

\begin{tabular}{|c|c|c|c|c|c|c|c|c|}
\hline $\begin{array}{c}\text { Item } \\
\text { No. }\end{array}$ & 1 & 2 & 3 & 4 & $\cdots$ & $\mathrm{i}$ & $\cdots$ & $\mathrm{b}$ \\
\hline Value & 1 & 3 & 9 & 27 & $\cdots$ & $3^{\mathrm{i}-1}$ & $\cdots$ & $3^{\mathrm{b}-1}$ \\
\hline $\mathrm{S}_{\mathrm{i}}$ & 1 & 4 & 13 & 40 & $\cdots$ & $\frac{3^{i}-1}{2}$ & $\cdots$ & $\frac{3^{b}-1}{2}$ \\
\hline
\end{tabular}

\section{C: Special progressions}

Special progressions are designed for laddered multilevel inverters. We have:

- Luo-Progression;

- Ye-Progression.

(1) Luo-Progression is a new progression that is deferent from any existing progression such as arithmetical progressions, geometric progressions and so on. The value of each item is the twice of the sum of the all previous items plus 1 From the $3^{\text {rd }}$ item:

$$
V_{i}=\left\{\begin{array}{cc}
i & i \leq 2 \\
7 \times 3^{i-2} & i \geq 3
\end{array}\right.
$$

The sum of the items from the first item to ith item is $\mathrm{Si}$,

$S_{i}=\sum_{k=1}^{i} V_{k}=\frac{7 \times 3^{i-2}-1}{2} \quad i \geq 2$

Luo-Progression is listed in Table 6. The sum of the items from 1 to the $\mathrm{i}^{\text {th }}$ item $\mathrm{S}_{\mathrm{i}}$ is $S_{i}=\frac{7 \times 3^{i-2}-1}{2}$ with $i \geq 2$.

Table 6. Luo-progression

\begin{tabular}{|c|c|c|c|c|c|c|c|}
\hline $\begin{array}{c}\text { Item } \\
\text { No. }\end{array}$ & 1 & 2 & 3 & 4 & $\mathrm{i}(\mathrm{i} \geq 3)$ & $\cdots$ & $\mathrm{b}$ \\
\hline Value, & 1 & 2 & 7 & 21 & $7 \times 3^{i-3}$ & $\cdots$ & $7 \times 3^{b-3}$ \\
\hline $\begin{array}{c}\text { Sum, } \\
\mathrm{Si}\end{array}$ & 1 & 3 & 10 & 31 & $\frac{7 \times 3^{i-2}-1}{2}$ & $\cdots$ & $\frac{7 \times 3^{b-2}-1}{2}$ \\
\hline
\end{tabular}

(2) Ye-Progression is a new progression that is deferent 
from any existing progression such as arithmetical progressions, geometric progressions and so on. The value of each item is the twice of the sum of the all previous items plus 1 From the 4th item:

$$
V_{i}=\left\{\begin{array}{cc}
i^{2}-u(i-2) & i \leq 3 \\
25 \times 3^{i-4} & i \geq 4
\end{array}\right.
$$

where $u(i-2)$ is the unit-step function. It is,

$$
u(i-2)= \begin{cases}0 & i=1 \\ 1 & i \geq 2\end{cases}
$$

The sum of the items from the first item to ith item is $\mathrm{Si}$,

$$
S_{i}=\sum_{k=1}^{i} V_{k}=\frac{25 \times 3^{i-3}-1}{2} \quad i \geq 3
$$

Ye-Progression is listed in Table 7. The sum of the items from 1 to the $\mathrm{i}^{\text {th }}$ item $\mathrm{S}_{\mathrm{i}}$ is $=\frac{25 \times 3^{i-3}-1}{2}$ with $i \geq 3$.

Table 7. Ye-progression

\begin{tabular}{|c|c|c|c|c|c|c|c|c|}
\hline $\begin{array}{c}\text { Item } \\
\text { No. }\end{array}$ & 1 & 2 & 3 & 4 & 5 & $\ldots$ & $\mathrm{i}(\mathrm{i} \geq 4)$ & $\mathrm{b}$ \\
\hline $\begin{array}{c}\text { Valu } \\
\mathrm{e},\end{array}$ & 1 & 3 & 8 & 25 & 75 & $\cdots$ & $25 \times 3^{i-4}$ & $25 \times 3^{b-4}$ \\
\cline { 1 - 1 } $\begin{array}{c}\text { Sum, } \\
\mathrm{Si}\end{array}$ & 1 & 3 & 12 & 37 & 112 & $\cdots$ & $\frac{25 \times 3^{i-3}-1}{2}$ & $\frac{25 \times 3^{b-3}-1}{2}$ \\
\hline
\end{tabular}

\section{Laddered Multilevel DC/AC Inverters}

\section{A: Toggle Switch and Change-over Switch}

We use Toggle-switch as shown in Figure 1 (a), it is also called one-pole two-throw (1P2T) switch. The switch has one wiper pole (W) and two contact position "a" and "b". We define the switch is on meaning the wiper pole linked to position " $a$ "; otherwise the switch is off meaning the wiper pole linked to position " $b$ ". The terminal voltage of $V_{\mathrm{WN}}$ is equal to $\mathrm{V}_{\mathrm{dc}}$ during switch-on as shown in Figure 1 (c), and 0 during switch-off as shown in Figure 1 (b).

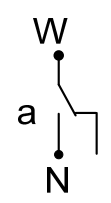

(a)

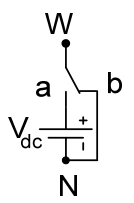

(b)

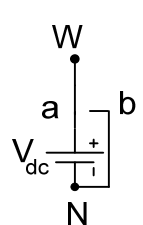

(c)

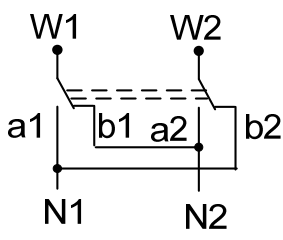

(d)
Figure 1. The Toggle-switch and Change-over Switch: (a) Toggle-switch (b) Toggle-switch off with a battery $V_{d c}$ (c) Switched on (d) Change-over Switch

A two-pole two-throw (2P2T) switch is shown in Figure 1 (d). It can reverse the output voltage from the input voltage. We define that the input voltage is $V_{\mathrm{w} 1 \mathrm{~W} 2}$ and the output voltage is $\mathrm{V}_{\mathrm{N} 1 \mathrm{~N} 2}$.

$V_{\text {out }}=V_{N 1 N 2}= \begin{cases}V_{W 1 W 2} & \text { switch is on } \\ -V_{W 1 W 2} & \text { switch is off }\end{cases}$

\section{B: General Circuit of Ladder Inverters}

General Circuit of Ladder Inverters is shown in Figure 2. It is a symmetrical circuit refers to the neutral point $\mathrm{N}$, i.e. there are two wings: positive wing and negative wing. Each wing has $b$ sets of the toggle-switch with a switch $S_{i}$ and battery $\mathrm{V}_{\text {dci }}$ [where $\mathrm{i}=-\mathrm{b},-(\mathrm{b}-1), \ldots-2,-1,1,2, \ldots \mathrm{b}-1$ and b]. " $b$ " is the Ladder stage number; " $n$ " is the total level number. The positive wing contents the b sets; " $i$ " is the $i^{\text {th }}$ set number. The negative wing contents the same sets (symmetrically). Therefore, we have,

$$
V_{d c-i}=-V_{d c i} \quad \mathrm{i}=1,2, \ldots \mathrm{b}-1, \mathrm{~b}
$$

To simplify the analysis, we assume the load is a purely resistive load $R$. 


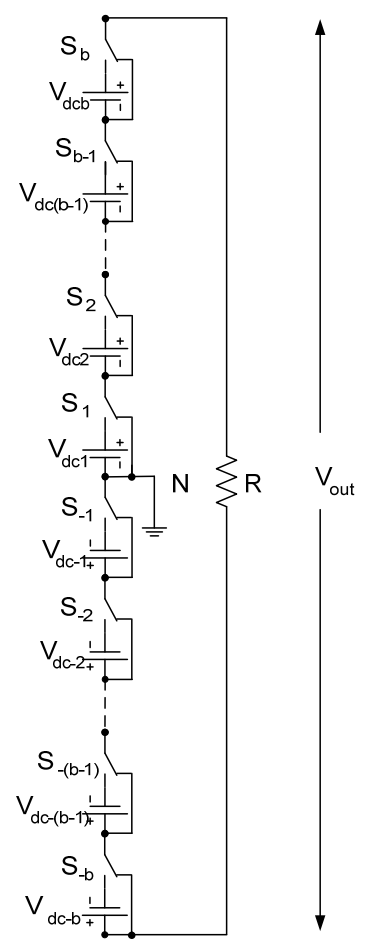

Figure 2. The General Circuit of Ladder Inverters

\section{C: Linear Ladder Inverters (LLI)}

If we choose all DC voltages $\mathrm{V}_{\mathrm{dci}}$ to be same voltage $\mathrm{E}$ in Figure 2, we obtain the Linear Ladder Inverters (LLI). This ladder was constructed as a Unit progression. The output voltage $\mathrm{V}_{\text {out }}$ has $\mathrm{n}$ levels, $\mathrm{n}=2 \mathrm{~b}+1$.

$$
\left|V_{d c i}\right|=E \quad \mathrm{i}=-\mathrm{b}, \ldots-1,1, \ldots \mathrm{b}
$$

The operation status is shown below:

- $\mathrm{V}_{\text {out }}=\mathrm{bE}$ : All positive wing switches on (others are off);

- $\mathrm{V}_{\text {out }}=(\mathrm{b}-1) \mathrm{E}$ : Switches $\mathrm{S}_{1}-\mathrm{S}_{\mathrm{b}-1}$ are on (others are off);

- $\quad \cdots . .$.

- $\mathrm{V}_{\text {out }}=2 \mathrm{E}$ : Switches $\mathrm{S}_{1}-\mathrm{S}_{2}$ are on (others are off);

- $\mathrm{V}_{\text {out }}=\mathrm{E}$ : only Switch $\mathrm{S}_{1}$ is on (others are off);

- $\mathrm{V}_{\text {out }}=0$ : All Switches are off;

- $\mathrm{V}_{\text {out }}=-\mathrm{E}$ : only Switch $\mathrm{S}_{-1}$ is on (others are off);

- $\mathrm{V}_{\text {out }}=-2 \mathrm{E}$ : Switches $\mathrm{S}_{-1}-\mathrm{S}_{-2}$ are on (others are off);

- $\quad \ldots . .$.

- $\mathrm{V}_{\text {out }}=-(\mathrm{b}-1) \mathrm{E}$ : Switches $\mathrm{S}_{-1}-\mathrm{S}_{-(\mathrm{b}-1)}$ are on (others are off);

- $\mathrm{V}_{\text {out }}=-\mathrm{bE}$ : All negative wing switches on (others are off).
We obtain $n=2 b+1$ levels. For example, if $b=3$, we have the total level number $n=7$ levels. The output voltage waveform is shown in Figure 3 (a).

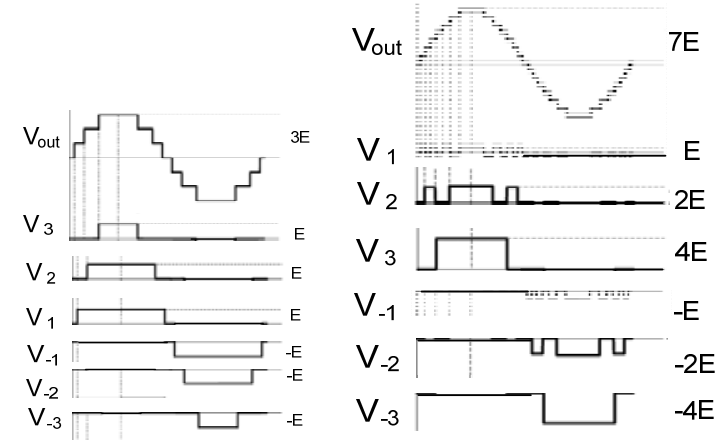

(a) 7-levels

(b) 15-levels

Figure 3. Multi-level output voltage waveform

\section{D: Natural Number Ladder Inverters (NNLI)}

If we choose all $\mathrm{DC}$ voltages $\mathrm{V}_{\mathrm{dci}}$ to be the voltage $\mathrm{iE}$ in Figure 2, we obtain the Natural Number Ladder Inverters (NNLI). This ladder was constructed as a Natural Number progression. The output voltage $\mathrm{V}_{\text {out }}$ has $\mathrm{n}$ levels, $n=b^{2}+b+1$ (refer to Table 2).

$$
V_{d c i}=\mathrm{i} E \quad \mathrm{i}=-\mathrm{b}, \ldots-1,1, \ldots \mathrm{b}
$$

The operation status is shown below:

- $\mathrm{V}_{\text {out }}=\mathrm{nE}$ : All positive wing switches on (others are off);

- $\mathrm{V}_{\text {out }}=(\mathrm{n}-1) \mathrm{E}$ : Switches $\mathrm{S}_{2}-\mathrm{S}_{\mathrm{b}}$ are on (others are off);

- $\quad$.......

- $\mathrm{V}_{\text {out }}=2 \mathrm{E}$ : only Switch $\mathrm{S}_{2}$ is on (others are off);

- $\mathrm{V}_{\text {out }}=\mathrm{E}$ : only Switch $\mathrm{S}_{1}$ is on (others are off);

- $\mathrm{V}_{\text {out }}=0$ : All Switches are off;

- $\mathrm{V}_{\text {out }}=-\mathrm{E}$ : only Switch $\mathrm{S}_{-1}$ is on (others are off);

- $\mathrm{V}_{\text {out }}=-2 \mathrm{E}$ : only Switch $\mathrm{S}_{-2}$ is on (others are off);

- $\quad$......

- $\mathrm{V}_{\text {out }}=-(\mathrm{n}-1) \mathrm{E}$ : Switches $\mathrm{S}_{-2}-\mathrm{S}_{-\mathrm{b}}$ are on (others are off);

- $\mathrm{V}_{\text {out }}=-\mathrm{nE}$ : All negative wing switches on (others are off).

We obtain $n=b^{2}+b+1$ levels. For example, if $b=3$, we have the total level number $n=13$ levels. 


\section{E: Odd number Ladder Inverters (ONLI)}

If we choose all DC voltages $\mathrm{V}_{\mathrm{dci}}$ to be the voltage $(2 \mathrm{i}-1) \mathrm{E}$ (in positive wing) in Figure 2, we obtain the Odd number Ladder Inverters (ONLI). This ladder was constructed as an Odd number progression. The output voltage Vout has $n$ levels, $n=2 b^{2}+1$ (refer to Table 3 ).

$V_{d c i}=\left\{\begin{array}{lc}(2 i-1) E & \mathrm{i} \geq 1 \\ (2 i+1) E & \mathrm{i} \leq-1\end{array}\right.$

The operation status is shown below:

- $\quad \mathrm{V}_{\text {out }}=\mathrm{b}^{2} \mathrm{E}$ : All positive wing switches on (others are off);

- $\mathrm{V}_{\text {out }}=\left(\mathrm{b}^{2}-1\right) \mathrm{E}$ : Switches $\mathrm{S}_{2}-\mathrm{S}_{\mathrm{b}}$ are on (others are off);

- $\quad \ldots . .$. .

- $\mathrm{V}_{\text {out }}=3 \mathrm{E}$ : only Switch $\mathrm{S}_{2}$ is on (others are off);

- $\mathrm{V}_{\text {out }}=2 \mathrm{E}$ : Switch $\mathrm{S}_{2}$ and $\mathrm{S}_{-1}$ are on (others are off);

- $\mathrm{V}_{\text {out }}=\mathrm{E}$ : only Switch $\mathrm{S}_{1}$ is on (others are off);

- $\mathrm{V}_{\text {out }}=0$ : All Switches are off;

- $\mathrm{V}_{\text {out }}=-\mathrm{E}$ : only Switch $\mathrm{S}_{-1}$ is on (others are off);

- $\mathrm{V}_{\text {out }}=-2 \mathrm{E}$ : Switch $\mathrm{S}_{-2}$ and $\mathrm{S}_{1}$ are on (others are off);

- $\mathrm{V}_{\text {out }}=-3 \mathrm{E}$ : only Switch $\mathrm{S}_{-2}$ is on (others are off);

- $\quad$......

- $\mathrm{V}_{\text {out }}=-\left(\mathrm{b}^{2}-1\right) \mathrm{E}$ : Switches $\mathrm{S}_{-2}-\mathrm{S}_{-\mathrm{b}}$ are on (others are off);

- $\mathrm{V}_{\text {out }}=-\mathrm{b}^{2} \mathrm{E}$ : All negative wing switches on (others are off)

We obtain $n=2 b^{2}+1$ levels. For example, if $b=3$, we have the total level number $n=19$ levels.

\section{F: Binary Ladder Inverters (BLI)}

If we choose all $\mathrm{DC}$ voltages $\mathrm{V}_{\mathrm{dci}}$ to be the voltage (2i-1)E in Figure 2, we obtain the Binary Ladder Inverters (BLI). This ladder was constructed as an Binary progression. The output voltage Vout has $n$ levels, $n=2^{b+1}-1$ (refer to Table 4).

If we choose the $\mathrm{DC}$ voltages $\mathrm{V}_{\mathrm{dci}}$ to be binary voltage in Figure 2.

$$
V_{d c i}=\left\{\begin{array}{cc}
2^{i-1} E & \mathrm{i} \geq 1 \\
-2^{-i-1} E & \mathrm{i} \leq-1
\end{array}\right.
$$

We obtain the Binary Ladder Inverters (BLI). The output voltage $\mathrm{V}_{\text {out }}$ has $\mathrm{n}$ levels, $\mathrm{n}=2^{\mathrm{b}+1}-1$.

The operation status is shown below:

- $\mathrm{V}_{\text {out }}=\left(2^{\mathrm{b}-1}-1\right) \mathrm{E}$ : All positive wing switches on (others are off);

- $\quad \ldots . .$.

- $\mathrm{V}_{\text {out }}=3 \mathrm{E}$ : Switches $\mathrm{S}_{1}-\mathrm{S}_{2}$ are on (others are off);

- $\mathrm{V}_{\text {out }}=2 \mathrm{E}$ : only Switch $\mathrm{S}_{2}$ is on (others are off);

- $\mathrm{V}_{\text {out }}=\mathrm{E}$ : only Switch $\mathrm{S}_{1}$ is on (others are off);

- $\mathrm{V}_{\text {out }}=0$ : All Switches are off;

- $\mathrm{V}_{\text {out }}=-\mathrm{E}$ : only Switch $\mathrm{S}_{-1}$ is on (others are off);

- $\mathrm{V}_{\text {out }}=-2 \mathrm{E}$ : only Switch $\mathrm{S}_{-2}$ is on (others are off);

- $\mathrm{V}_{\text {out }}=-3 \mathrm{E}$ : Switches $\mathrm{S}_{-1}-\mathrm{S}_{-2}$ are on (others are off);

- $\quad \ldots . .$.

- $\mathrm{V}_{\text {out }}=-\left(2^{\mathrm{b}-1}-1\right) \mathrm{E}$ : All negative wing switches on (others are off).

We obtain $n=2^{b+1}-1$ levels. For example, if $b=3$, we have an $\mathrm{n}=15$ levels output voltage waveform as shown in Figure 3 (b).

\section{G: Modified Binary Ladder Inverters (MBLI)}

The Modified Binary Ladder Inverters (MBLI) is shown in Figure 4. We used a two-pole two-throw switch, and save a half of the batteries and switches.

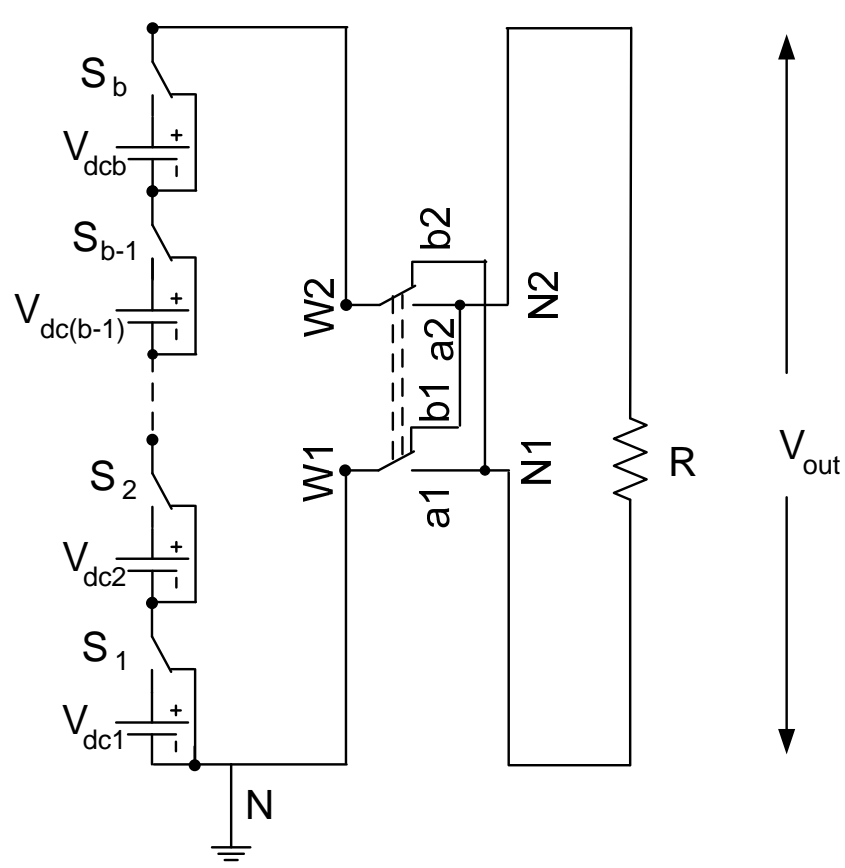

Figure 4. The Modified Binary Ladder Inverters 
We use a 2P2T switch exchange the output voltage polarity, and can save half of the total 1P2T switches and batteries in the negative wing. The operation status and output voltage waveform can refer to the Section $2 \mathrm{~F}$ (also Figure 3 (b)). The output voltage $\mathrm{V}_{\text {out }}$ has $\mathrm{n}$ levels, $\mathrm{n}=2^{\mathrm{b}+1}-1$.

\section{H: Luo-Progression (Series) Ladder Inverters (LPLI)}

In the research process we defined a new progression (series), and called it Luo-Progression (Series). It is different from all existing progressions such as the arithmetical progression, geometric progression and so on. We still use the symbols as " $b$ " is the progression stage number: " $i$ " is the $i^{\text {th }}$ item; $V_{i}$ is the $i^{\text {th }}$ item value; " $n$ " is the total value (sum). We define:

$V_{i}=\left\{\begin{array}{cc}i & i \leq 2 \\ 7 \times 3^{i-2} & i \geq 3\end{array}\right.$

The total level's number $\mathrm{n}$ is

$n=\left(2 \times \sum_{i=1}^{b} V_{i}\right)+1=7 \times 3^{b-2} \quad b \geq 2$

Table 8: Luo-Progression (continued)

\begin{tabular}{|l|c|c|c|c|c|c|c|l|}
\hline $\begin{array}{l}\text { stage } \\
\text { No. }\end{array}$ & 1 & 2 & 3 & 4 & 5 & 6 & $\mathrm{i}^{\text {th }}(\mathrm{i} \geq 3)$ & $\mathrm{b}$ \\
\hline $\begin{array}{l}\text { Item } \\
\text { Value }_{\mathrm{i}}\end{array}$ & 1 & 2 & 7 & 21 & 63 & 189 & $7 \times 3^{i-3}$ & $7 \times 3^{b-3}$ \\
\hline $\begin{array}{l}\text { Sum, } \\
\mathrm{S}_{\mathrm{i}}\end{array}$ & 1 & 3 & 10 & 31 & 94 & 283 & $\frac{7 \times 3^{i-2}-1}{2}$ & $\frac{7 \times 3^{b-2}-}{2}$ \\
\hline $\begin{array}{l}\text { total } \\
\text { levels }\end{array}$ & 3 & 7 & 21 & 63 & 189 & 567 & $7 \times 3^{i-2}$ & $7 \times 3^{b-2}$ \\
\hline
\end{tabular}

From Table 8 if we construct a ladder with 4 stages $(b=4)$ in each wing, we can obtain 63 levels $(n=63)$. We still assume the level unit is "E". The operation status is shown below:

- $\mathrm{V}_{\text {out }}=31 \mathrm{E}$ : All positive wing switches on (others are off);

- $\quad \ldots . .$.

- $\mathrm{V}_{\text {out }}=4 \mathrm{E}$ : Switches $\mathrm{S}_{3}, \mathrm{~S}_{-1}-\mathrm{S}_{-2}$ are on (others are off);

- $\mathrm{V}_{\text {out }}=3 \mathrm{E}$ : Switches $\mathrm{S}_{1}-\mathrm{S}_{2}$ are on (others are off);

- $\mathrm{V}_{\text {out }}=2 \mathrm{E}$ : only Switch $\mathrm{S}_{2}$ is on (others are off);

- $\mathrm{V}_{\text {out }}=\mathrm{E}$ : only Switch $\mathrm{S}_{1}$ is on (others are off);

- $\mathrm{V}_{\text {out }}=0$ : All Switches are off;

- $\mathrm{V}_{\text {out }}=-\mathrm{E}$ : only Switch $\mathrm{S}_{-1}$ is on (others are off);
- $\mathrm{V}_{\text {out }}=-3 \mathrm{E}$ : Switches $\mathrm{S}_{-1}-\mathrm{S}_{-2}$ are on (others are off);

- $\mathrm{V}_{\text {out }}=-4 \mathrm{E}$ : Switches, $\mathrm{S}_{-3}, \mathrm{~S}_{1}-\mathrm{S}_{2}$ are on (others are off);

- $\quad \ldots . .$.

- $\mathrm{V}_{\text {out }}=-31 \mathrm{E}$ : All negative wing switches on (others are off).

\section{I: Ye-Progression Ladder Inverters (YPLI)}

In our research process we invent and defined another new progression, and called it Ye-Progression. It is different from all existing progressions such as the arithmetical progression, geometric progression and so on. We still use the symbols as " $b$ " is the progression stage number: " $i$ " is the ith item; $\mathrm{Vi}$ is the ith item value; $\mathrm{Si}$ is the sum value; " $n$ "is the level number. We define:

$V_{i}=\left\{\begin{array}{cc}i^{2}-u(i-2) & i \leq 3 \\ 25 \times 3^{i-4} & i \geq 4\end{array}\right.$

The total levels, $\mathrm{n}$ is

$n=\left(2 \times \sum_{i=1}^{b} V_{i}\right)+1=25 \times 3^{b-3} \quad b \geq 3$

Table 9. Ye-Progression (continued)

\begin{tabular}{|l|c|c|c|c|c|c|c|l|}
\hline $\begin{array}{l}\text { stage } \\
\text { No. }\end{array}$ & 1 & 2 & 3 & 4 & 5 & 6 & ith $(\mathrm{i} \geq 4)$ & $\mathrm{b}$ \\
\hline $\begin{array}{l}\text { Item } \\
\text { Valu } \\
\mathrm{e}\end{array}$ & 1 & 3 & 8 & 25 & 75 & 225 & $25 \times 3^{i-4}$ & $25 \times 3^{b-4}$ \\
\hline $\begin{array}{l}\text { Sum, } \\
\mathrm{Si}\end{array}$ & 1 & 4 & 12 & 37 & 112 & 337 & $\frac{25 \times 3^{i-3}-1}{2}$ & $\frac{25 \times 3^{b-3}-1}{2}$ \\
\hline $\begin{array}{l}\text { total } \\
\text { level } \\
\text { s }\end{array}$ & 3 & 9 & 25 & 75 & 225 & 675 & $25 \times 3^{i-3}$ & $25 \times 3^{b-3}$ \\
\hline
\end{tabular}

From Table 9, if we construct a ladder with 4 stages $(b=4)$ in both wing, we can obtain 75 levels $(n=75)$. We still assume the level unit is " $E$ ". The operation status is shown below:

- $\quad$ Vout = 37E: All positive wing switches on (others are off);

- $\quad$......

- $\quad$ Vout $=4 \mathrm{E}:$ Switches S1 and S3 are on (others are off);

- Vout = 3E: only Switch S2 is on (others are off);

- Vout = 2E: Switches S2 and S-1 are on (others are off);

- Vout = E: only Switch S1 is on (others are off);

- $\quad$ Vout =0: All Switches are off; 
- $\quad$ Vout = -E: only Switch S-1 is on (others are off);

- Vout =-2E: Switches S-2 and S1 are on (others off);

- Vout = -3E: only Switch S-2 is on (others are off);

- Vout = - 4E: Switches S-1 and S-2 are on (others are off);

- $\quad \ldots . .$.

- $\quad$ Vout = - 37E: All negative wing switches on (others are off).

\section{J: Trinary Ladder Inverters (TLI)}

If we choose the $\mathrm{DC}$ voltages $\mathrm{V}_{\mathrm{dci}}$ to be trinary voltage in Figure 4

$$
V_{d c i}=3^{i-1} E \quad \mathrm{i}=1, \ldots \mathrm{b}-1, \mathrm{~b}
$$

We have got the Trinary Ladder Inverters (TLI). The total level number $n=3^{i}$.

The operation status is shown below:

- $\quad \mathrm{V}_{\text {out }}=\left(3^{\mathrm{b}-1}-1\right) \mathrm{E}$ : All positive wing switches on (others are off);

- $\quad \cdots . .$.

- $\mathrm{V}_{\text {out }}=3 \mathrm{E}$ : only Switch $\mathrm{S}_{2}$ is on (others are off);

- $\mathrm{V}_{\text {out }}=2 \mathrm{E}$ : Switches $\mathrm{S}_{2}$ and $\mathrm{S}_{-1}$ are on (others are off);

- $\mathrm{V}_{\text {out }}=\mathrm{E}$ : only Switch $\mathrm{S}_{1}$ is on (others are off);

- $\mathrm{V}_{\text {out }}=0$ : All Switches are off;

- $\mathrm{V}_{\text {out }}=-\mathrm{E}$ : only Switch $\mathrm{S}_{-1}$ is on (others are off);

- $\mathrm{V}_{\text {out }}=-2 \mathrm{E}$ : Switches $\mathrm{S}_{1}$ and $\mathrm{S}_{-2}$ are on (others are off);

- $\mathrm{V}_{\text {out }}=-3 \mathrm{E}$ : only Switch $\mathrm{S}_{-2}$ is on (others are off);

- $\quad$......

- $\mathrm{V}_{\text {out }}=-\left(2^{\mathrm{b}-1}-1\right) \mathrm{E}$ : All negative wing switches on (others are off)

We obtain $n=3^{b+1}$ levels. For example, if $b=3$, we have an $\mathrm{n}=81$ levels

\section{COMPARISON WITH ALL LADDER INVERTERS}

We introduce 8 types of Ladder Inverters in Section III. In order to catch the clue of all Ladder Inverters and some other inverters,

- $\quad$ LLI - Linear Ladder Inverters

- $\quad$ NNLI - Natural Number Ladder Inverters

- ONLI - Odd number Ladder Inverters

- BLI - Binary Ladder Inverters

- $\quad$ MBLI - Modified Binary Ladder Inverters

- $\quad$ LPLI - Luo-Progression (Series) Ladder Inverters

- YPLI - Ye-Progression (Series) Ladder Inverters

- $\quad$ TLI - Trinary Ladder Inverters

- NPCI - Neutral-Point Clamped Inverters

\section{- $\quad$ LHBI - linear H-Bridged Inverters}

We compare with them in the table 10 .

\section{SOlAR PANEL ENERGy SYSTEMS}

The sun is a star in the universe; the earth is a planet surrounding the sun. The earth flies in an oval orbit surrounding the sun, the sun is locates in a focus of the oval orbit. The average distance between sun and earth is about $150 \mathrm{Mkm}(150,000,000$ kilometers $)$. The sun radiates the power $3.8 \times 10^{20} \mathrm{MW}$ into the space. Our Earth receives $174 \times 10^{9} \mathrm{MW}$ from the Sun.

The solar panel is constructed by the solar cell (or photovoltaic cell), which belongs to a wide multidisciplinary area. It converts solar energy into electricity by the photovoltaic effect. Briefly to sort the solar cells into two groups: monocrystalline and multicrystalline silicon wafer. Figure 5(a) shows a solar cell made from a monocrystalline silicon wafer.

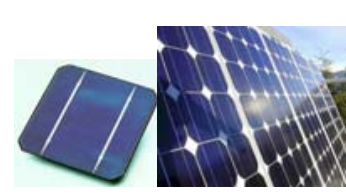

(a)

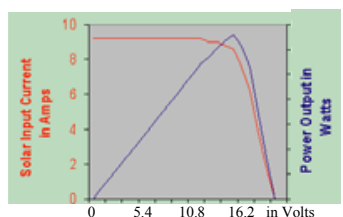

(c)
Figure 5. Solar panel: (a) A solar cell, (b) An approach of solar panel, (c) The theoretical power/Current curves

The overall approach is shown in Figure 5(b), which is assembled by few solar cells. The theoretical solar panel system (a certain solar panel) power/current curves are shown in Figure 5(c). The current (from the solar panel) is nearly constant in the low voltage (from the solar panel) regain. When the input voltage reaches $16.2 \mathrm{~V}$, the input current sharply reduces to zero. The blue curve is the output power with its maximum power point (MPP) at $132 \mathrm{~W}$.

We set the voltage unit $\mathrm{E}=16.2 \mathrm{~V}$. It is easy to construct the batteries for a BLI:

- $\mathrm{V}_{\mathrm{dc} 1}=\mathrm{V}_{\mathrm{dc}-1}=\mathrm{E}=16.2 \mathrm{~V}$

- $\mathrm{V}_{\mathrm{dc} 2}=\mathrm{V}_{\mathrm{dc}-2}=2 \mathrm{E}=32.4 \mathrm{~V}$

- $\mathrm{V}_{\mathrm{dc} 3}=\mathrm{V}_{\mathrm{dc}-3}=4 \mathrm{E}=64.8 \mathrm{~V}$

\section{SIMULATION AND EXPERIMENTAL RESULTS}

We use a BLI with $b=3$ to do the simulation. The output voltage has 15 levels. The simulation result is shown in Figure 6 (a). The corresponding experimental result is shown in Figure $6(\mathrm{~b})$. 


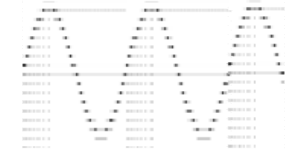

(a)

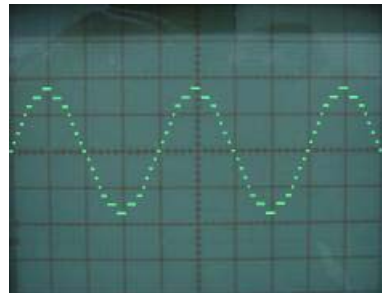

(b)
Figure 6. A 15 level BLI: (a) The simulation result, (b) The experimental result

We use a LPLI with $b=3$ to do the simulation again. The output voltage has 21 levels. The simulation result is shown in Figure 7 (a). The corresponding experimental result is shown in Figure 7 (b).

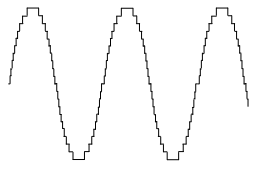

(a)

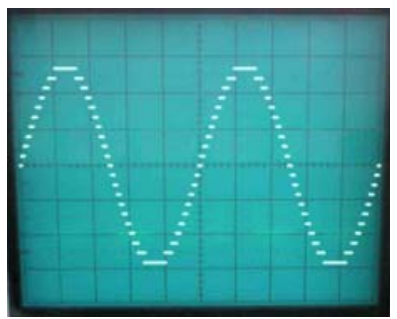

(b)
Figure 7. A 21 level LPLI: (a) The simulation result, (b) The experimental result

\section{CONCLUSION}

This paper introduces 8 Laddered Multilevel Inverters. All Laddered Multilevel inverters have simple structure, clear operation procedure, easy control and more output voltage levels. We can use less components to construct more level output voltage, therefore the cost is lower. The solar panels are naturally dependent/floating DC sources (likely batteries). Authors use a BLI and LPLI to a solar panel energy system, and obtain the satisfied simulation and experimental results. It is strongly support our circuit design. We believe these Laddered Multilevel Inverters will be used in other renewable energy systems and other industrial applications soon.

\section{References:}

1. Luo F. L. and Ye H. "Power Electronics: Advanced Conversion Technologies" Taylor and Francis Group LLC, Boca Raton, Florida 07030, USA, 2010. ISBN: 978-1-4200-9429-9.

2. Nabae, A., Takahashi, I. and Akagi, H. "A NeutralPoint Clamped PWM Inverter", Proceedings of IEEE APEC'80 Conference, 1980, pp. 761-766.

3. Nabae, A., Takahashi, I. and Akagi, H. "A NeutralPoint Clamped PWM Inverter" IEEE Transactions on Industry Applications, 1981, pp. 518-523.

4. Luo F. L. and Ye H. "Advanced DC/DC Converters" CRC Press LLC, Boca Raton, Florida 07030, USA, 2004. ISBN: 0-8493-1956-0.

5. Peng, F. Z. "A generalized multilevel inverter topology with self voltage balancing", IEEE Transactions on Industry Applications, 2001, pp $611-618$.

6. Liu Y. and Luo F. L. "Trinary Hybrid 81-level Multilevel Inverter for Motor Drive with Zero Common-Mode Voltage" IEEE-Transactions on Industrial Electronics, Vol. 55, No. 3, March 2008, pp. 1014-1021.

7. Liu Y. and Luo F. L. "Multilevel Inverter with the Ability of Self Voltage Balancing" IEE- Proceedings on Electric Power Applications, Vol. 153, No. 1, January 2006, pp. 105-115.

8. Liu Y. and Luo F. L. "Trinary Hybrid Multilevel Inverter Used in STATCOM with Unbalanced Voltages" IEE- Proceedings on Electric Power Applications, Vol. 152, No. 5, September 2005, pp. 1203-1222.

Table 10. Comparison with all Ladder Inverters and some other inverters

\begin{tabular}{|c|c|c|c|c|c|c|c|c|c|c|}
\hline $\begin{array}{c}\text { Inverter } \\
\mathrm{s}\end{array}$ & $\begin{array}{c}\mathrm{LL} \\
\mathrm{I}\end{array}$ & $\begin{array}{l}\mathrm{NN} \\
\mathrm{LI}\end{array}$ & $\begin{array}{r}\text { ON } \\
\text { LI }\end{array}$ & $\begin{array}{l}\text { B } \\
\text { LI }\end{array}$ & $\begin{array}{r}\text { MB } \\
\text { LI }\end{array}$ & $\begin{array}{l}\mathrm{L} \\
\mathrm{P} \\
\mathrm{LI}\end{array}$ & $\begin{array}{c}\text { YPL } \\
\text { I }\end{array}$ & $\begin{array}{c}\mathrm{T} \\
\mathrm{LI}\end{array}$ & $\begin{array}{l}\mathrm{NP} \\
\mathrm{CI}\end{array}$ & $\begin{array}{l}\mathrm{L} \\
\mathrm{H} \\
\mathrm{BI}\end{array}$ \\
\hline $\begin{array}{l}\mathrm{b}, \text { stage } \\
\text { number }\end{array}$ & $2 b$ & $2 b$ & $2 b$ & $2 b$ & $\mathrm{~b}$ & $2 b$ & $2 b$ & $2 b$ & $2 b$ & $\mathrm{~b}$ \\
\hline $\begin{array}{l}\text { Battery } \\
\text { number }\end{array}$ & $2 b$ & $2 b$ & $2 b$ & $2 b$ & $\mathrm{~b}$ & $2 b$ & $2 b$ & $2 b$ & $1 / 2$ & $\mathrm{~b}$ \\
\hline $\begin{array}{l}\text { Switch } \\
\text { number }\end{array}$ & $2 b$ & $2 b$ & $2 b$ & $2 b$ & $b+1$ & $2 b$ & $2 b$ & $2 b$ & $4 \mathrm{~b}$ & $4 \mathrm{~b}$ \\
\hline $\begin{array}{l}\text { Capacito } \\
\text { r number }\end{array}$ & 0 & 0 & 0 & 0 & 0 & 0 & 0 & 0 & $2 b$ & 0 \\
\hline
\end{tabular}




\begin{tabular}{|c|c|c|c|c|c|c|c|c|c|c|}
\hline $\begin{array}{c}\text { Diode } \\
\text { number }\end{array}$ & 0 & 0 & 0 & 0 & 0 & 0 & 0 & 0 & $4 b-2$ & $4 \mathrm{~b}$ \\
\hline $\mathrm{n}$, total & $2 b$ & $b^{2}+b$ & $b^{2}+$ & $2^{b+1}-$ & $2^{b+1}$ & $7 x$ & $25 \mathrm{x}$ & $3^{b}$ & $2 b+1$ & $2 b$ \\
\hline levels & +1 & +1 & 1 & 1 & 1 & $3^{b-2}$ & $3^{b-3}$ & & & +1 \\
\hline
\end{tabular}

For example, if $\mathrm{b}=3$, we obtain the level numbers for each Inverter as shown in Table 11.

Table 11. Comparison with the Inverters (if $\mathrm{b}=3$ )

\begin{tabular}{|c|c|c|c|c|c|c|c|c|c|c|}
\hline $\begin{array}{c}\text { Inverter } \\
\text { s }\end{array}$ & $\begin{array}{c}\text { L } \\
\text { LI }\end{array}$ & $\begin{array}{r}\text { NN } \\
\text { LI }\end{array}$ & $\begin{array}{r}\text { LN } \\
\text { LI }\end{array}$ & $\begin{array}{c}\text { B } \\
\text { LI }\end{array}$ & $\begin{array}{r}\text { MB } \\
\text { LI }\end{array}$ & $\begin{array}{c}\text { L } \\
\text { P } \\
\text { LI }\end{array}$ & $\begin{array}{c}\text { Y } \\
\text { P } \\
\text { LI }\end{array}$ & $\begin{array}{c}\text { T } \\
\text { LI }\end{array}$ & $\begin{array}{c}\text { NP } \\
\text { CI }\end{array}$ & $\begin{array}{c}\text { LH } \\
\text { BI }\end{array}$ \\
\hline $\begin{array}{c}\text { stage } \\
\text { number }\end{array}$ & 6 & 6 & 6 & 6 & 3 & 6 & 6 & 6 & 6 & 3 \\
\hline $\begin{array}{c}\text { Battery } \\
\text { number }\end{array}$ & 6 & 6 & 6 & 6 & 3 & 6 & 6 & 6 & $1 / 2$ & 3 \\
\hline $\begin{array}{c}\text { Switch } \\
\text { number }\end{array}$ & 6 & 6 & 6 & 6 & 4 & 6 & 6 & 6 & 12 & 12 \\
\hline $\begin{array}{c}\text { Capacito } \\
\text { number }\end{array}$ & 0 & 0 & 0 & 0 & 0 & 0 & 0 & 0 & 6 & 0 \\
\hline $\begin{array}{c}\text { Diode } \\
\text { number }\end{array}$ & 0 & 0 & 0 & 0 & 0 & 0 & 0 & 0 & 10 & 12 \\
\hline $\begin{array}{c}\text { n, total } \\
\text { levels }\end{array}$ & 7 & 13 & 19 & 15 & 15 & 21 & 25 & 27 & 7 & 7 \\
\hline
\end{tabular}

For example, if $\mathrm{b}=5$, we obtain the level numbers for each Inverter as shown in Table 12.

Table 12. Comparison with the Inverters (if $\mathrm{b}=5$ )

\begin{tabular}{|c|c|c|c|c|c|c|c|c|c|c|}
\hline Inverter & LL & & $\mathrm{ON}$ & "B & $\mathrm{MB}$ & "LPL & $\overline{~ Y \mathrm{YP}}$ & T & "NP & LH \\
\hline $\mathrm{s}$ & I & LI & LI & LI & $\mathrm{LI}$ & I & LI & LI & $\mathrm{CI}$ & BI \\
\hline $\begin{array}{l}\text { stage } \\
\text { number }\end{array}$ & 10 & 10 & 10 & 10 & 5 & 10 & 10 & 10 & 10 & 5 \\
\hline $\begin{array}{l}\text { Battery } \\
\text { number }\end{array}$ & 10 & 10 & 10 & 10 & 5 & 10 & 10 & 10 & $1 / 2$ & 5 \\
\hline $\begin{array}{l}\text { Switch } \\
\text { number }\end{array}$ & 10 & 10 & 10 & 10 & 6 & 10 & 10 & 10 & 20 & 20 \\
\hline $\begin{array}{l}\text { Capacito } \\
\text { r number }\end{array}$ & 0 & 0 & 0 & 0 & 0 & 0 & 0 & 0 & 10 & 0 \\
\hline $\begin{array}{l}\text { Diode } \\
\text { number }\end{array}$ & 0 & 0 & 0 & 0 & 0 & 0 & 0 & 0 & 18 & 20 \\
\hline $\begin{array}{l}\mathrm{n} \text {, total } \\
\text { levels }\end{array}$ & 11 & 31 & 51 & 63 & 63 & 189 & 225 & 243 & 11 & 11 \\
\hline
\end{tabular}

From Tables 10 - 12, it can obviously be seen that the Trinary Ladder Inverter (TLI), Ye-Progression Ladder Inverter (LPLI) and Luo-Progression Ladder Inverter (LPLI) use fewer components and yield higher number of levels. For example, if we choose $\mathrm{b}=5$ we obtain 243 levels by using TLI, 225 levels by using YPLI and 189 levels by using LPLI with only 10 batteries and 10 switches. 